\title{
Alexandra PoulaIn, Irish Drama, Modernity and the Passion Play, London, Palgrave Macmillan, 2016
}

\section{Hélène Lecossois}

\section{(2) OpenEdition}

\section{Journals}

\section{Electronic version}

URL: http://journals.openedition.org/etudesirlandaises/5393

DOI: 10.4000/etudesirlandaises.5393

ISSN: 2259-8863

\section{Publisher}

Presses universitaires de Caen

\section{Printed version}

Date of publication: 29 November 2017

Number of pages: $156-157$

ISBN: 978-2-7535-7388-8

ISSN: 0183-973X

\section{Electronic reference}

Hélène Lecossois, « Alexandra Poulain, Irish Drama, Modernity and the Passion Play, London, Palgrave Macmillan, 2016 », Études irlandaises [Online], 42-2 | 2017, Online since 29 November 2017, connection on 24 September 2020. URL : http://journals.openedition.org/etudesirlandaises/5393 ; DOI : https:// doi.org/10.4000/etudesirlandaises.5393

\section{(c) (i) (8)}

Études irlandaises est mise à disposition selon les termes de la Licence Creative Commons Attribution - Pas d'Utilisation Commerciale - Partage dans les Mêmes Conditions 4.0 International. 
fixation on the confessional after the 1801 Act of Union, with current debates surrounding clerical child abuse. In one of the strongest essays in the collection, Anne Fogarty draws parallels between the censorship of Kate O'Brien's The Land of Spices and that text's concern with sexual repression, the feminine, and the unspoken, arguing that silence is an integral aspect of the symbolic structures of The Land of Spices and reveals the ways that the condition of modern Ireland affected female development. In a fascinating exploration of the language of signs and images Stephanie Schwerter discusses the challenges of translating Belfast's urban murals into different cultural environments and what is silenced by translation. Thierry Robin's penultimate essay suggests that Dermot Healy's A Fool's Errand interweaves silence and speech in order to merge past and future, living and dead. Finally, the Collection ends on a haunting note with Virginie Roche-Tiengo's demonstration of the ways that the dead impact on the silences of the living in Brian Friel's drama.

In its vast scope of essays, from the psychic to the topographic, which touch on questions of gender, place, belonging, testimony, language, and death, Silence in Modern Irish Literature leaves a necessary stain on the silence that has too long suppressed voices that are only now beginning to be heard. In its focus on gaps and ruptures in speech, Silence in Modern Irish Literature marks a unique and important contribution to Irish Studies, one that alters approaches to reading practices themselves by shifting the focus from what is articulated, to what remains unspoken, but which nevertheless conveys meaning.

Bridget ENGLISH

Alexandra Poulain, Irish Drama, Modernity and the Passion Play, London, Palgrave Macmillan, 2016, 264 p., ISBN 978-1-349-94962-5, \$99.99 (hardcover), ISBN 978-1-349-94963-2, \$79.99 (ebook).

Irish Drama, Modernity and the Passion Play is a welcome, refreshing contribution to critical studies of twentieth-century Irish drama. It takes its readers on a journey to varied, often unexplored corners as it engages with a wide and eclectic range of plays. Its detailed and contextualised close readings highlight the richness and complexity of the field of twentieth-century Irish theatre. The book looks anew at canonical plays, such as, for example, J. M. Synge's The Playboy of the Western World (1907), W. B. Yeats's Calvary (1920), Samuel Beckett's Endgame (1957), Brian Friel's Faith Healer (1979) or Tom Murphy's Bailegangaire (1985). Crucially, it also offers perceptive analyses of lesser known plays 
such as, for example, Augusta Gregory's The Story Brought by Brigit (1923-1924), Padraig Pearse's An Ri / The King (1912), Owen (1913), The Master (1915) and The Singer (1916-1917), G. B. Shaw's Saint Joan (1923), Samuel Beckett's radio plays (Words and Music (1961), Cascando (1961), Rough for Radio II (1976), as well as an unpublished play The Press (2007) by the distinguished cultural critic David Lloyd.

The originality of the book lies in its identifying the Passion as one of the recurring dramaturgical paradigms which define twentieth-century Irish drama. Alexandra Poulain apprehends the Passion play as a lay narrative or spectacle of sacrifice which testifies to the sufferings of the martyred hero and of silenced others, rather than simply as a rewriting of the Passion of Christ in the strict sense of the word. Thus the book argues that the display of the martyred body - or of its effects on an on-stage audience - is a way to restore to visibility forms of violence which are usually hidden from view. As such the Passion constitutes a powerfully efficient political intervention. The particular nature of the oppressive norms which the Passion renders visible varies according to the historical contexts in which the plays were written or first produced. Prominent amongst these forms of oppression figure the sectarianism of Ireland's (post)colonial states and the sometimes homogenising norms presiding over the definitions of a national or a gendered identity.

Poulain's close readings are consistently illuminating. Chapter 3 challenges widely accepted readings of Padraig Pearse's plays as testifying to a fascination for death and blood sacrifice and argues instead that the plays perform "the pragmatic political task of making colonial violence visible" (79). Focusing on Saint Joan, G. B. Shaw's take on the Easter Rising, chapter 5 highlights the power of the Passion to destabilize patriarchal and sectarian conceptions of nationalism. Chapter 11 proposes a compelling analysis of Beckett's radio plays as artistic and political interventions demanding a compassionate and ethical response from their auditors. Since Words for Music, Cascando and Rough for Radio II were written for the radio, the Passion does not serve to render violence visible. 'Instead,' Alexandra Poulain argues, "relocating ethics in the vulnerable, pathological subject, [the plays] ask that we dispense with the certainty of visuality, listen to the pain and recognise it as, partly, our own" (222).

The combination of close readings and fascinating critical perspective makes Irish Drama, Modernity and the Passion Play an important book for Irish studies in general, and Irish theatre in particular.

Hélène Lecossois 